\title{
表具にみられる和紙の接着 \\ Adhesion of Japanese Washi Papers for Fabrication and Restoration of Kakejiku
}

\section{1. 緒 言}

楮や三榗などを主原料とする日本の和紙は，かって日常 生活の中で様々に使われていたが, その用途の大半は木材 パルプを主原料とする洋紙に取って代わられた。今日，和 紙を目にすることは少なくなったが，和紙が未だ賞用され る特殊用途としては，墨のにじみに独特の味わいがあると して書道用，あるいは掛け軸の表具など古文化財の修復用 などが挙げられる。

伝統的な和紙そのあのの製造に際して，また書画におけ る和紙の使用に際して接着機構が関与する過程はほとんど 無いが, 掛け軸の工程では和紙の接着が, さらにその修復 では剥離および接着が極めて大きな役割を果たす。ここで は掛け軸の制作および修理に際して伝統的に使用する和紙, そこで使用する糊，さらにそれらの貼り合わせや剥離にお ける特殊な技術を通して日本の伝統の中にある接着の一例 を解説する。

\section{2. 表具とは何か}

表具または表装とは単に美術品である絵や菖（表具の分 野では本紙と称する）を飾る付属品ではなく，本紙を書き， あるいは描いた人格に対する尊敬の心の表現である。従っ て, 掛け軸を鑑賞する場合, その表具が如何に本紙を生か しているか，また，掛けられる場に調和したものであるか どうかを見ることが大切になる（図1参照)。すなわち, 掛け軸の着ている衣裳と言うべき本紙周辺の裂地の組み合 わせが床の間之釣り合いの良いものであるか, そして本紙 に対して映りのよいむのであるか，そうした事も含めて掛

\section{* (㑣) 宇佐美修徳堂}

京都市左京区松ヶ崎西山 15-2 于 606-0933

Usami Shutokudo Inc.

15-2 Nishiyama Matsugasaki Sakyo-ku Kyoto 606-0933 Japan

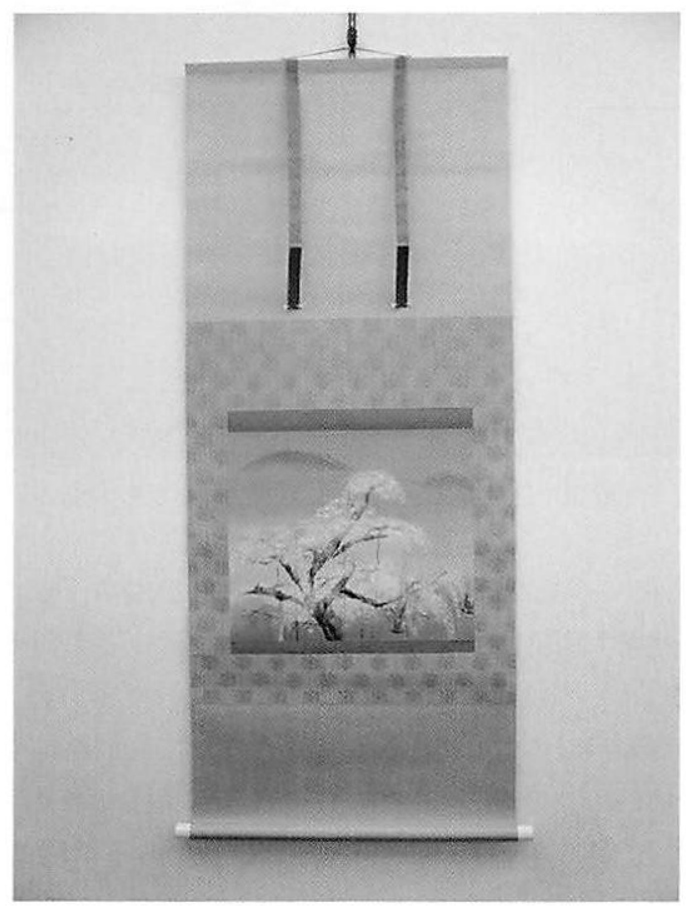

図 1 掛け軸装，三段表具：富田渓仙先生画

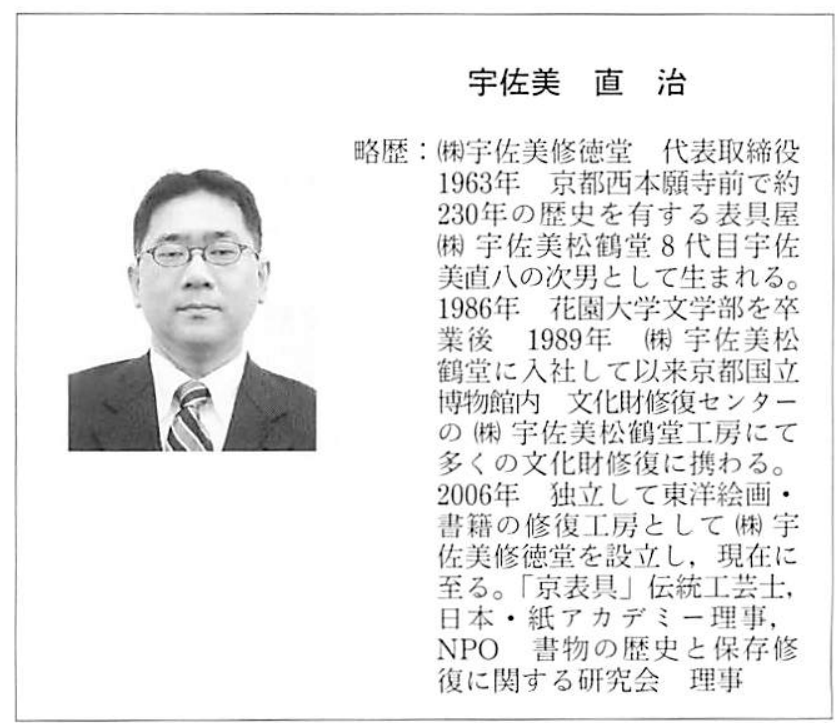




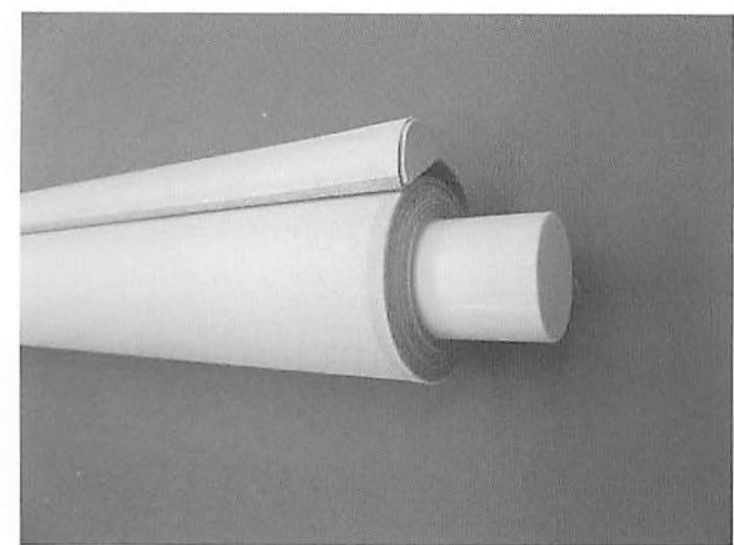

図 2 巻かれた掛け軸を側面から見る。

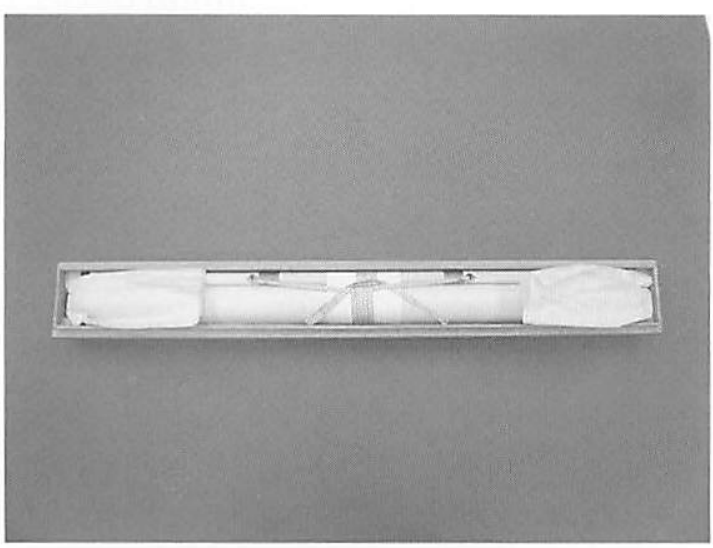

図 3 巻かれて保存箱に収納された掛け軸

け軸として本紙を鑑賞することにより，日本の「床の間の 美」，世界に類のない「掛け軸」の美の真の姿を同う事が できる。

掛け軸とは，絵画や菖を軸に巻き付けて長期保存や収納 に便利なように工夫された表具の代表的装法であり，壁に 掛けて鑑賞できるように作られたものである（図 2,3 参 照）。他に類似した装法として，机上で順次広げながら鑑 覚あるいは読めるようにした巻き物（巻子装）あ軸装であ る。表具上は，これら以外に屏風や襖に仕立てたもの，あ るいは経じて冊子や一定幅で折本に仕立てたものもある。 これらの中で最も複雑で高度な技術を必要上するのが掛け 軸である。ここでは脚け軸を通した表具における接着をそ こでの和紙と糊の役割に注目して概観する。

\section{3. 表具で使用する材料とその役割}

\section{1 表具で使用する和紙}

掛け軸などを製作や修復する際には大きく二つの側面で 「和紙」が使用されている。一つは文化財の本紙の欠落等 を補修するために使用するもの，もう一つは表からは見え ない部分で本紙を補强するものである。表装や文化財の修 復において「和紙」は大变重要な役割をはたしている。

日本絵画や古文書等は，主に和紙や絹等の素材の上に墨
や顔料などで描かれあるいは营かれており、これら素材の 耐久性は絹と比べて，和紙の方が強いと言える。また，良 質な和紙を良好な環境で保存した場合，警くほよ゙長期間製 作時の状態を維持できる事例もある。しかし，一般的に日 本絵画や古文書等の文化財が現在まで受け継がれてきた理 由としては, 約 100 年每に修復を繰り返し行ってきた事が 挙げられる。

修復のため解装した時に，軸木に墨菖で書かれた以前の 修復の銘に出遭うこともある。また, 以前の修復の技術を 確認することもできる。墨苩がなくても, 現在まで伝わっ てきた絵画や古文昔等を見ると, 本紙の裹面より全面補強 としての和紙と糊を使った「裹打ち：紙の裹貼りによる補 強で，厚さ調整も兼祆る」以外に，必ずと言ってよいほよ゙ 欠損筒所の「縜い」や，折れが生じている個所の「折伏せ： 局部的に細く切った和紙をあてて，補強する」等の修復痕 跡が見られる。いずれも，古来より修復には「和紙」上 「糊」による接着が欠かせないものであった事を物語る。 さらに，本紙が和紙ではなく絹等に描かれているものや， 染織品の修復にも和紙による「裹打ち」が行われ，和紙と 糊の接着は文化財保存の基本と考えられる。

絵面や古文菖等が製作された時は, そのものの材料であ る和紙や絹等いずれも一枚の状態で製作された物が，それ らを鑑賞する時の装飾や保存及び収納のために，巻子装や 掛け軸装等にされる。そこでの主な工程は本紙自体を丈夫 にするための，和紙による「裹打ち」である。この作業は， 後述する本紙の肌裏・増し裏・ 中裏・総裹の各裹打ち, 屏 風では下張り等の諸工程に分類できるが，いずれにせよ装 丁・修復作業の中でも基本的かつ，最も重要な技法である。 何故ならば，とくに肌裹では本紙の裹面に直接接触するか らでもある。修復の際の「㒷打ち」は，和紙に描かれたあ るいは昔かれた本紙は勿論のこと, 絹等の粉末状に劣化し つつある本紙に対しても行われる。すなわち以前の技術者 が施した古い裏打ち紙を除去して後, 現代に製作された張 りのある新しい裹打ち紙を用いて裹打ちを行う。たとえ損 傷の激しい本紙でも肌裹を和紙で打ち替えてやるだけで再 び製作時の「張り」を取り戻すことができる。それは絹本 （本紙が絹材）の場合でも同じ事が言える。これらの作業 は修復技術の一つの工程にすぎないが，このような作業の 繰り返しによって古来より受継がれてきた文化遗産を次の 世代に伝承する事ができるのである。それには，和紙が必 ず使われている。そして，そこでの和紙は文化財である本 紙にとっても安全かつ長期保存に優れた和紙であるべきで, そのため古来からの技法で㵂かれた和紙が必要になる。

和紙は，その原料として䅦・三桠・隻皮等で作られてい る。㒂紙だけでも美濃の薄美濃紙・本美濃紙, 吉野の美栖 紙や宇陀紙, さらに黒谷紙, 石州紙等があり, 産地ごとに 特色が異なり，挙げればきりがないが，それらを表具や修 
復の用途に合わせて選択する。この他に修復現場での大切 な作業の一つに失部分を和紙で縜うという根気のいる重 要な作業すある。繕い紙の選択の他, あらゆる工程で, ど のような和紙を使用することが最適であるかを吟味するの が修復家の力ともいえる。そこには, 長年の技術と経験が 必要であるが, それに加えてより良い修復を施し, 後世に 美術品等を良い状態で残すために事前の調査や研究が必要 になる。

3.1 .1 表具で使用する代表的和紙 掛け軸の工程において使用される一般的な和紙は「美濃 紙・美栖紙・宇陀紙」である。掛け軸は繰り返して巻かれ 保存され，また鑑賞や飾り付けの際には床に掛けられるが, その際には自荷重が掛かるので強度的性質が重要である。 そのため, 数有る和紙の中でも美濃紙はそれが有する優れ た強度的性質故に日本古来の美術品の主要な形態である掛 け軸の工程に多く用いられてきた。他方屏風や襖等の建具 に使用される一般的な和紙は「石州紙・黒谷紙・間似合紙」 等である。

（1）薄美濃紙（岐阜・美濃和紙，図 4 参照）

薄手の代表的な楮紙であり，肌裏紙として使用される。 本紙の裏には全て肌裏が施されているが, 修復に際しては 本紙の永年の污れやアク等を吸い込み弱ったこの古い肌裹 紙を取り除く。その後, 本紙の色調を考虑して, 草木染め, 顔料, 墨等を用いて染めた「薄美濃紙」を用いて再び新し く肌裹を裹打ちする。古い肌裹紙をこの新しい和紙に取り 替えてやることによって本紙に張りが更生り, 次世代に文化 財を伝えることが出来る。上述の「折伏せ」には薄美濃紙 を幅一分 $(3 \mathrm{~mm})$ 弱に細長く切った紙を用意する。折れ の発生していた箇所やその恐れのある個所に補強のために 水で薄めた薄糊（水糊とも称する）で貼り合わせる。これ により折れはなくなり, 表面から見ると, 折机の見えない 伸びた本紙になる。その他掛け軸装の一文字, 中緣, 総縁 等の表装裂（図 5 参照）を安定させ, 補強するために薄美 濃紙で肌裏打ちを行う。

（2）美栖紙（奈良・吉野和紙）

薄手から厚手まで各種の厚みのある楮紙で, 紙自身にし なやかさを出すために填料として胡粉を入れ, さらに压搾 工程を省いて乾燥されている。肌裹紙だけでは厚みや弾力 性が足りない場合, 本紙と表具裂の「硬さ」*の調子が合 わない時や掛け軸自身に厚みをつけたい時等に古糊を使っ てこの美栖紙なよ゙で裏打ちを施し，後述するように「打ち 刷毛」を打つことでさらに接着力を高めると共に厚みや柔 軟度を調製する。

*本紙と表具裂はそれぞれ素材，厚み，柔軟度が異なる。

（3）宇陀紙（奈良・吉野和紙）

薄手から厚手まで各種の厚みのある柏紙で, 紙自身にし なやかさと共に表面が滑らかで引き締まった紙質を出すた

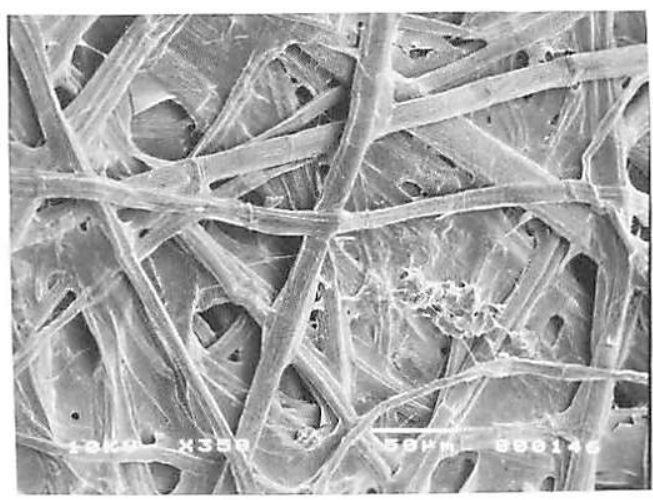

図 4 電子顕微鏡で見た美濃紙の表面 ${ }^{2)}$

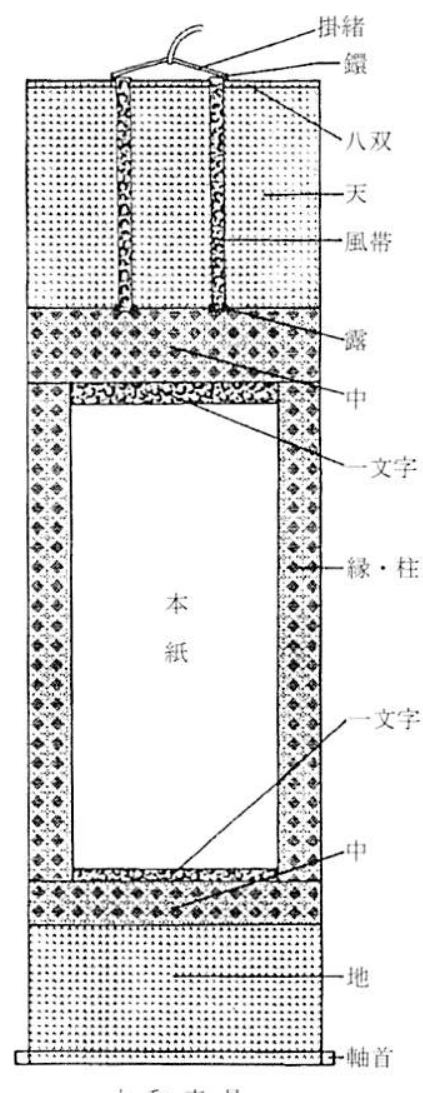

大和表具

図 5 軸装表具各部の名称

めに填料として白土が入れてある。掛け軸自体の背面に最 後に裏打ちを行う総裹用の和紙で古糊を使って裹打ちを施 し, ここでも「打ち刷毛」を打つことで接着力を高めてい る。

このほかにも，黑谷和紙（京都・黒谷和紙）は屏風の尾 背部分に，襖等の建具の下張には石州紙（島根・石州紙） や間似合紙（兵庫・名塩紙）等を使う。黑谷和紙・石州紙 は楮紙，間似合紙は榷皮紙である。また裏打ちそのものに は使われないが, 敷紙や, 仮営生など, 修復工程の途中で 臨時的に用いる紙としてレーヨン紙がある。和紙ではない か，機械抄きであり，ロール状で入手できるので，任意の 形状で利用できて，しかも穴偠であり，多用されている。 つまり, 上述したようにそれぞれの種類の「紙」の特徵を 


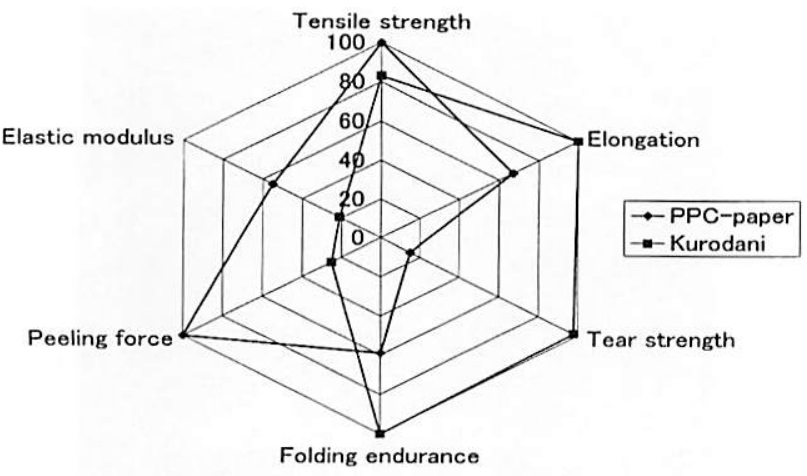

図6コピー用紙と黑谷紙の強度比較 ${ }^{2)}$

充分理解してから上手に利用し，掛け軸を制作している。

数多くある和紙の中から, 表具や修復の工程で和紙は適 材適所で用いられているが，これら表具で主に用いられる 和紙の強度的性質を，洋紙のそれと比較してその特街を明 らかにした研究がある2)。その結果によれば，和紙の坪量 （面積あたりの質量：代表的新聞紙及びコピー紙ではそれ ぞれ $42,60 \mathrm{~g} / \mathrm{m}^{2}$ である) は概して小さく，和紙は比較的薄 くて密度の低い嵩高い紙が多い。図 6 は各種力学的物性値 (引張強度 : Tensile strength, 弾性率 : Elastic modulus, 引張伸び : Elongation, 引裂強度: Tear strength, 而折 強度：Folding endurance, 剥離強度 : Peeling force) ${ }^{3}$ のレーザーチャートである。洋紙に比べて和紙が低密度で あるのに対応して弾性率は小さく, 織維間結合はあまり発 達していないので，柔らかい感触を与える。ところが，繊 維間結合がそしいにも拘わらず紙面方向の各强度は概して 大きく，とくに引裂强度や耐折強度は極めて大きい。

\section{2 表具に使用する糊}

表具に使用するむう一つの材料は紙の接着に使用する糊 である。ここでも適材適所として接着力の大きい新糊と小 さい古糊が，またさらに嶩度む加隇しつつ利用されている。

(1) 新糊

純粋な小麦測粉を沈生㟣と言い，純白の粉末あるいは塊 である。この小麦激粉 $350 \mathrm{~g}$ に対して水を約 $1 \ell$ 加えて溶 き，強火で約 10 分程度やや固くなるまで，その後は弱火 で約 30 分〜40 分程焦げつかないように擋找しながら煮た のが新糊である。これを陶器製の器に移し, 濡れ夕オルで 覆って, 約半日でゆっくり冷やして固まらせて貯える。そ の後不純物や不均一な糊の塊を除去するためなど, 必要に 応じて糊濾しで滤す。糊盆（サワラ材）に移した後は，さ らに刷毛で練ると共に作業内容に応じて水で薄め濃度を変 えて使用する（図 7 参照）。夏期で 7 日，冬李で 3 週間程 度が使用期限とされるが，房敗する前に使い切るため，必 要星をその度に調製する。

(2) 古糊

寒糊上も言う。一月の寒中の頃に新糊を大量に作り，裂

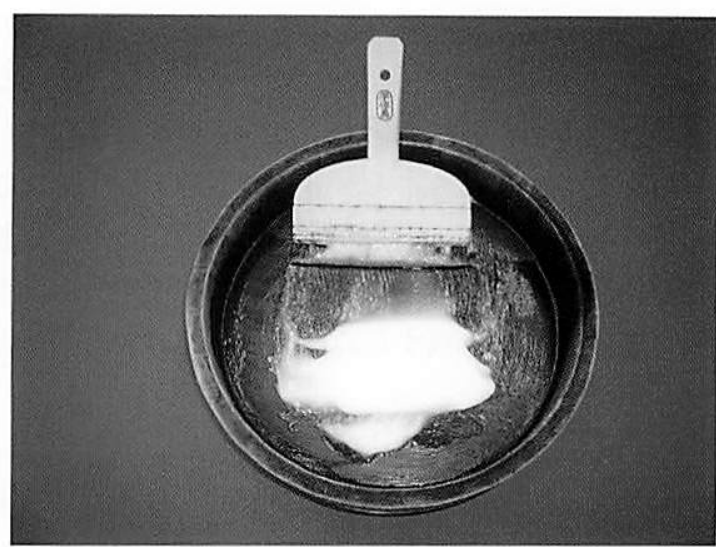

図 7 糊盆での新糊練りとその後の水希勫

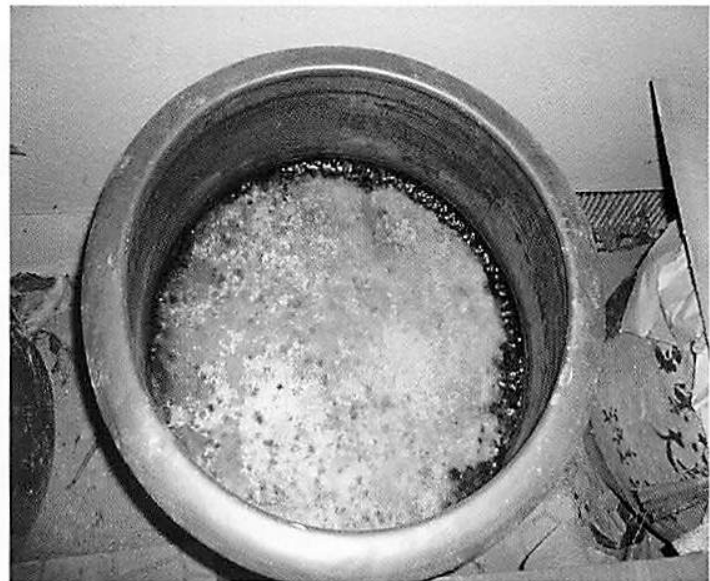

図 83 年目の古糊：カビの発生は多い。

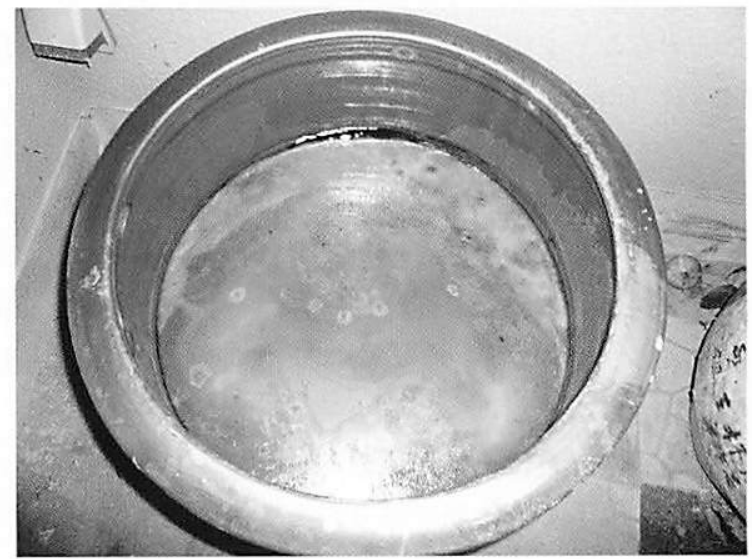

図 96 年目の古糊：カビの発生は少ない。

に眝えてカルキ抜き済みの水をその上に張って蓋をし，風 通しの良い冷暗所（休下等）に保管して調製する。この水 は毎年, 寒の頃に亥の中のカビなどを除去して後取り替え るが, 初めの間は, 水面に多量の力ビが発生する。数年経 つとそれは黒変し, 力ビの発生が次第に抑えられて約 6 年 から約 10 年で「古糊」となる（図 8,9 参照）。これは接 着力が弱く, 後述する増し㒷打ち, 中裹打ち, 総裹打ちに はこの古糊を水で薄めた水糊（薄糊とも称する）として使 用する。 


\section{（3）布海苔}

ふのり科の海藻から作られる。板状の乾燥布海苔はちぎっ て水中に一晚放置して膨潤させ，これを煮て溶かし，不溶 部分を滤し取って布海苔液とする。膠水に混ぜて絵の具止 めとしたり, 紙本の欠損部を別の紙で修復する際に糊と混 ぜたりして使用する。

(4) 表具用化学糊

酢酸ビニルエマルジョンに増粘効果のため, カルボキシ メチルセルロース（CMC）を混ぜた表具用合成樹脂接着 剤が市販されている。デンプン糊に比して, 接着層がやわ らかく, 湿度変化に伴うあばれが少ないと言われている。 さらに湿気に対して強く, 高湿下でも接着力を維持し, 一 方水を塗布すれば容易に剥離できる特徴を有する。ただし, 後述する「打ち刷毛」を使用した際の接着力の向上の有無 や経年使用後の性能变化など未解明の点も多いので, 文化 財の修復には用いない。

\section{4. 表具の技術}

\section{1 表具で使用する工具・道具類}

表具に用いられる道具類は，近代的な技術におけるそれ らと異なり，工房によって名前や使用法にあ差異がある。 ここでは標準的な道具の中で，とくに接着技法に関連した 刷毛について説明する。

(1) 糊刷毛

馬尾毛 (馬の尻尾) 製, 幅約 $150 \mathrm{~mm}$, 毛足約 $30 \mathrm{~mm}$ で 水糊や水で薄めない硬糊などの糊付け專用。

（2）付回し刷毛（切継刷毛）

馬尾毛・狸毛製。幅約 $150 \mathrm{~mm}$, 毛足約 $20 \mathrm{~mm}$ で硬糊を 幅狭く帯状に塗るために使用, 毛足が糊刷毛よりやや薄く かつ短い。

（3）水刷毛

鹿毛製。幅約 $150 \mathrm{~mm}$, 毛足約 $24 \mathrm{~mm}$ で水を与えるため の刷毛で, 糊刷毛より毛が厚い。

(4) 撫刷毛 (棕櫊刷毛)

棕㯗とくに津久毛製。幅約 $150 \mathrm{~mm}$, 毛足約 $65 \mathrm{~mm}$ で裏 打ちの後, 撫でっけるのに使用。

(5) 打刷毛

棕櫚とくに津久毛製。幅約 $150 \mathrm{~mm}$ ，毛足約 $90 \mathrm{~mm}$ ，毛 の厚み約 $30 \mathrm{~mm}$ (根元部分）で撫刷毛を用いて撫でっけ た後, さらによく接着させるためと称して, 毛先で紙面を 打つ作業に使用。

刷毛だけであ上記のように色々あり，これらを使い分け ている。

\section{2 和紙裹打ち (接着) 技法とその手順}

掛け軸には，新たに作製する以外に修復，すなわち表具 直しむ多い。以下は後者の場合を想定した接着作業手順で
(1)

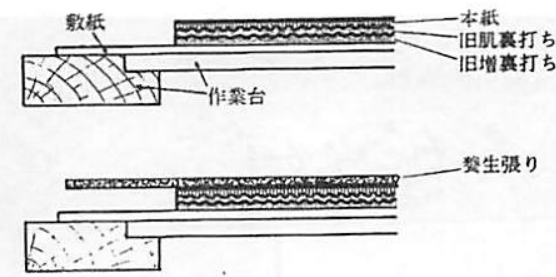

(3)

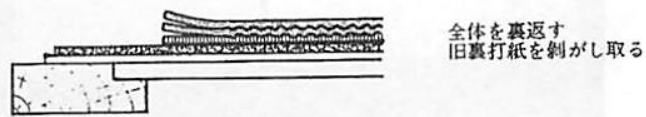

(4)

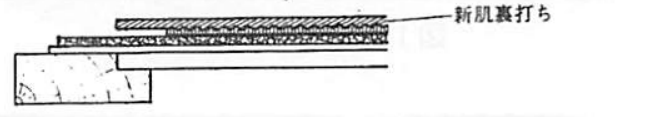

(5)

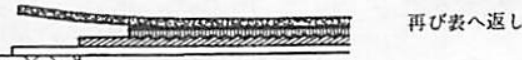

(6)

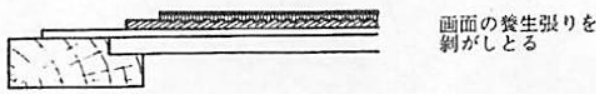

図 10 旧肌裏打ち紙の除去手順 ${ }^{1)}$

ある。なお新たに表具する場合は，当然，調查から本紙の 補修までの工程及び補修作業である折り伏せと補彩工程は 含まれないし，さらにここでは本紙周辺の裂（布地）の貼 り付け作業などについては省いてある1。

調査 $\rightarrow$ 記録 $\rightarrow$ 董蒸 $\rightarrow$ 剥落止 $\rightarrow$ 解装 $\rightarrow$ 養生 $($ 保護 $) \rightarrow$ 本紙の 旧裏打ち紙の除去 $\rightarrow$ 本紙の補修 $\rightarrow$ 肌裏打ち $\rightarrow$ 折り伏せ $\rightarrow$ 補 彩 $\rightarrow$ 表装裂の裹打ち $\rightarrow$ 本紙の増し裹打ち (厚み調整) $\rightarrow$ 表 装裂の増し裏打ち (厚み調整) $\rightarrow$ 付け迴し $\rightarrow$ 中裏打ち $\rightarrow$ 総 裏打ち $\rightarrow$ 乾燥 $\rightarrow$ 仕上げ

以下では再軸装における剥離と接着に直接関連する工程 についてさらに説明を加える（図 10 参照）。軸を取り除く など解装した後，(1) 敷紙（レーヨン紙系）の上に本紙の 画面を上向きに展へ，水分を与えて紙同士を接着している 糊をゆるめることでその接着力を無くす。(2) 画面養生（保 護）のため，表面に紙を水打ち（水分を与える）する。ま ず小さく切った薄用紙（レーヨン紙系）にも同様に水打ち し，さらに全面を覆う大判であ同様にして画面養生を行う。 (3) 次にこの状態で裹返して, 伏せ直し, 水分を与えなが ら旧裏打ち紙（総裹, 中裏, 増裏, 最後に肌裏の順で）を 除去する。この時本紙と直接接している肌裹紙の除去は丁 寧に行う。(4)次いで新た肌裏紙を貼り付ける肌裹打ちを 行う。(5) 再び表に返して後, (6) 画面養生の紙を除去する。 以下更に増し裹，中裹，総裏と裹打ちを重ねる。

新たに制作する場合の裹打ちを，写真と併せて解説する ことで，裏打ちすなわち表具における接着工程をより詳し 


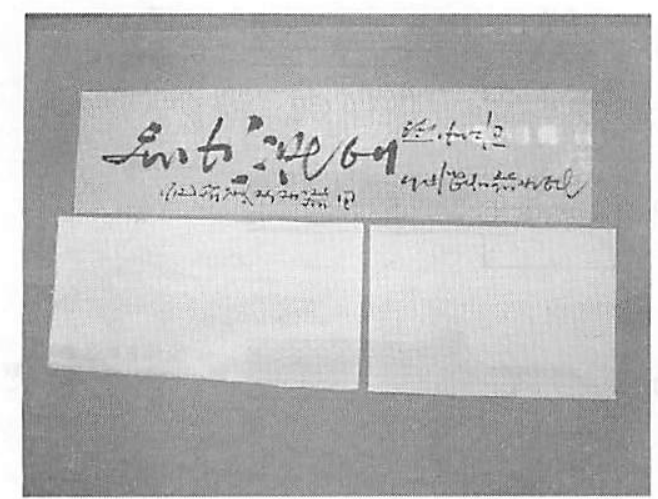

図 11 肌裏打ちの準備

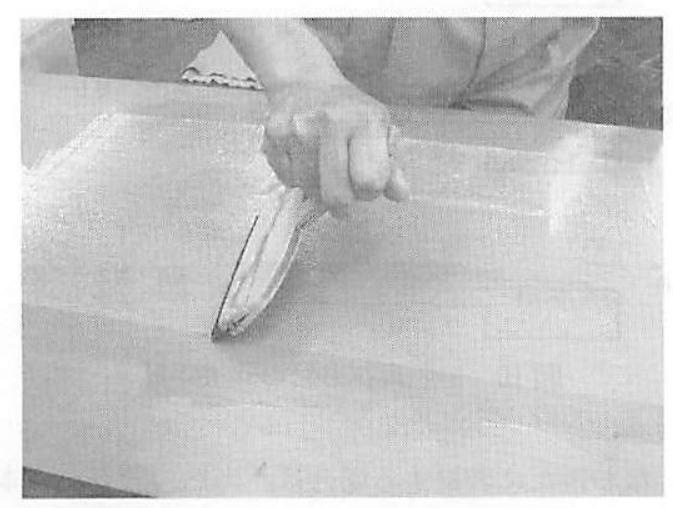

図 12 糊刷毛による塗布で薄糊を良く浸透させる。

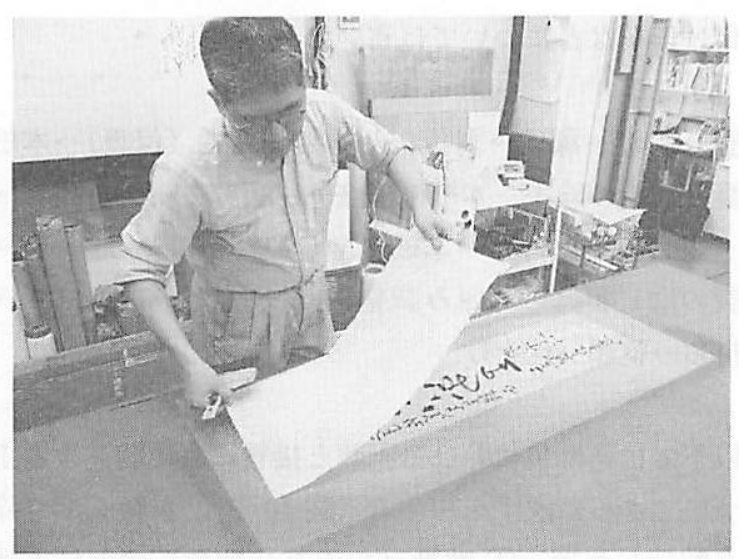

図 13 投げ打ち技法

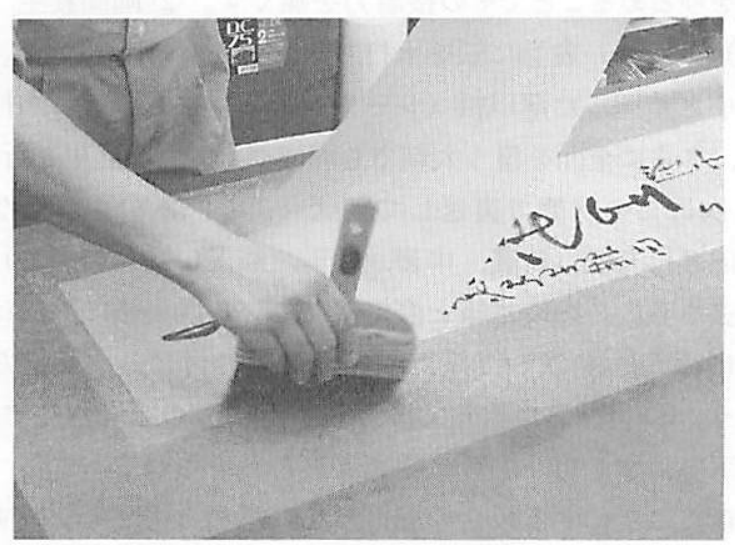

図 14 撫で刷毛の使用

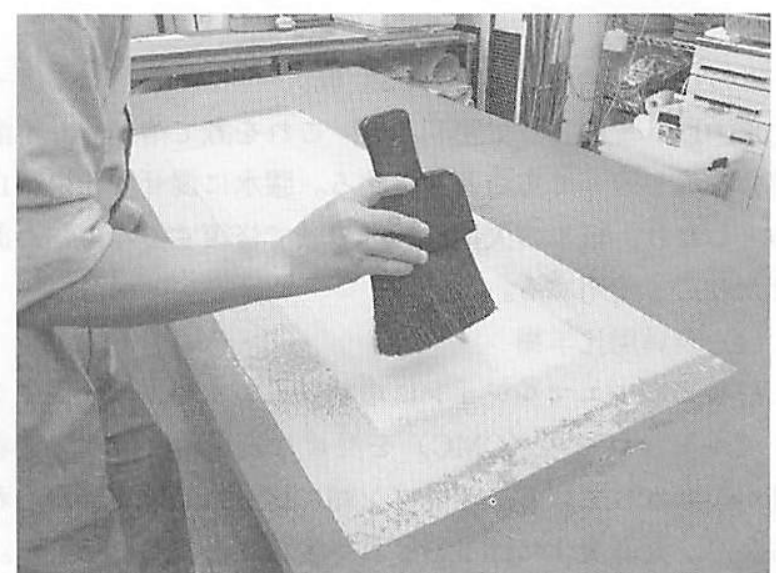

図 15 打ち刷毛で紙面を打つ。

く見てみよう。

まず敷紙を作業台に敷き，その上に本紙を伏せて置いて， 少量の水で刷毛引きしながら平らに延ばしておく。一方で 本紙と逆目（重なり合う2 枚の紙の繊維の配向が直角にな る）の裹打ち紙（肌哀紙，薄美濃紙）を準備する（図 11 参照)。白木の糊付け板 (イチョウ材が最適) の上に裏打 ち紙を置き, 紙全面に浸透するように水で薄めた薄糊を塗 布する (図 12 参照)。この糊付き裏打ち紙を本紙に重秝る ことで裹打ちを行う。写真は投げ打ち技法（図 13 参照） で重ねている様相であり, 間に空気が入らないように，ま た旇が出ないようにかつ斜めに成らないようにしながら， 撫で刷毛で撫でながら十分注意して行う（図 14 参照）。手 漉き和紙のサイズは大きくなく, 大抵必要なサイズに足り ないので，継ぐようにして（順目に揃えた紙の端を水で塗 布して，繊維を毛羽状態にして，恰も 1 枚の紙のように） 2 枚目も同様に裹打ちする。本紙全面に肌裹紙が裹打ちさ れると, 再度しっかり撫でる。

厚さ調製やさらなる補強のために, 増し裹やさらに中裹 打ちを行う。この工程では, 糊には接着力の弱い古糊をさ らに薄めて使用し, 中裹打ちの場合紙には美栖紙を使用す るが，この際紙の目（織維の配向方向）は最初の裏打ち紙 である肌裏紙と逆の目にする。この工程で大事なのは, 糊 塗布後む糊刷毛で十分しごいて粘りを出すと共に糊が十分 浸透することであり，さらに貼り会わせた後で「打ち刷毛」 を用いて，その毛先で紙面を打つことで肌裹紙と増し裏紙 次いで中裹紙の㵶維を絡めて (図 15 参照), 両者の接着を 強固にすることである。詳細は不明であるが, 恐らく投錨 効果が加わったものと考えられる。

\section{5. 終わりに}

すでに見てきたように，表具の世界は糊による和紙の接 着の世界である。ここにはまた保存と修復の必要性から接 着状態を元に戻すことも考えた知恵と千年以上の実績があ る。すなわち, 剥がして再度接着することの繰り返しであ 
り, そのためには和紙と糊の絶妙な組み合わせ, 水の介在 による糊接着の可逆性を基にした多様な糊の使い分け, さ らには裏打ちにおける「打ち刷毛」を主とする多くの接着 関連技法を必要とする。そして, そこには糊の塗布量や浸 透具合 (深さ方向の分布), 関連して糊の粘度などと接着 強度, さらに投錨効果との関連など未だ知られていない科 学が隠されている。

この日本の表具, 文化財修復技術は世界的にも極めてレ ベルが高いと言われており, 世界各地の博物館で修復作業 にいそしむ日本人むおられ，またその技術習得に世界から 京都に来られている方も多い。さらにかつては高䶘者の技 術であったが, 最近では若い技能者も増大しており, その 技術の伝承においても科学の裏付けが欠かせない。接着学 の観点から見た表具や保存科学についての今後の検討が期 待される次第である。
最後に本稿に種々ご助言を睗った京都大学農学研究科の 山内龍男先生に感謝申し上げる。

\section{引用文 献}

1）西川杏太郎編, 特別研究報告菖 “表具の科学” 東京国立文化 盼研究所, 23 (1977).

2) 山内龍男, 宇佐美直治, 紙パ技協誌 59, 1546 (2005).

3）山内龍男, “紙とパルプの科学” (学術選苩 018). 京都大学学術出版会 149 (2006).

\section{全体に関わる参考文献}

＊高橋正隆, “絵絹から書紙一”, 文華堂苩店 (1976).

*宇佐美直八監修, “表具の栞”芸岲堂 (1988).

* “在外日本美術の修復” 中央公論社 (1994).

*久米康生, “和紙文化辞典” わがみ堂 (1995).

*田邊三郎助・登戸建三監修 “美術工芸品の保存と保管” フジテ クノシステム (1995). 